\title{
Article
}

\section{Shifting Patterns of House Structures during the Neolithic-Bronze Age in the Yellow River Basin: An Environmental Perspective}

\author{
Peng Lu ${ }^{1,2, *,+}$, Yan Tian ${ }^{1,2, \dagger}$, Michael Storozum ${ }^{3,4}$, Panpan Chen ${ }^{1,2}$, Hui Wang ${ }^{5}$, Xia Wang ${ }^{1,2}$, Junjie Xu ${ }^{6}$, \\ Lei Jing ${ }^{1,2}$, Lijie Yan ${ }^{1,2}$, Li Zhang ${ }^{1,2}$ and Duowen Mo ${ }^{1,7, *}$
}

1 Institute of Geography, Henan Academy of Sciences, Zhengzhou 450052, China; tianyan@igs-has.cn (Y.T.); chenpanpan@igs-has.cn (P.C.); wangxia@igs-has.cn (X.W.); jinglei15@mails.ucas.edu.cn (L.J.); yanlj@igs-has.cn (L.Y.); zhangli@igs-has.cn (L.Z.)

2 Zhengzhou Base, International Center on Space Technologies for Natural and Cultural Heritage under the Auspices of UNESCO, Zhengzhou 450052, China

3 Institute of Archaeological Science, Fudan University, Shanghai 200433, China; mjstorozum@fudan.edu.cn

4 Department of Cultural Heritage and Museology, Fudan University, Shanghai 200433, China

5 The Institute of Archaeology, Chinese Academy of Social Sciences, Beijing 100710, China; wh@cass.org.cn

6 College of History, Zhengzhou University, Zhengzhou 450000, China; xujunjie@zzu.edu.cn

7 Laboratory for Earth Surface Processes, Ministry of Education, College of Urban and Environmental Sciences, Peking University, Beijing 100871, China

* Correspondence: lupeng@igs-has.cn (P.L.); dmo@urban.pku.edu.cn (D.M.)

$+\quad$ P.L. and Y.T. contributed equally to this study.

check for

updates

Citation: Lu, P.; Tian, Y.; Storozum,

M.; Chen, P.; Wang, H.; Wang, X.; Xu,

J.; Jing, L.; Yan, L.; Zhang, L.; et al.

Shifting Patterns of House Structures

during the Neolithic-Bronze Age in

the Yellow River Basin: An

Environmental Perspective. Land

2021, 10, 574. https://doi.org/

10.3390/land10060574

Academic Editor: Michael U. Hensel

Received: 23 March 2021

Accepted: 21 May 2021

Published: 28 May 2021

Publisher's Note: MDPI stays neutral with regard to jurisdictional claims in published maps and institutional affiliations.

Copyright: (c) 2021 by the authors. Licensee MDPI, Basel, Switzerland. This article is an open access article distributed under the terms and conditions of the Creative Commons Attribution (CC BY) license (https:/ / creativecommons.org/licenses/by/ $4.0 /)$.

\begin{abstract}
The emergence of houses is a social revolution around the world. Over the past several decades, Chinese archaeologists have excavated many Neolithic to Bronze Age houses, but there is still a great amount of uncertainty about the social and environmental factors driving the differences between these house structures in the Yellow River Basin. In this paper, we summarize data from excavation reports on the shape and size of Neolithic-Bronze Age houses in the upper, middle and lower reaches of the Yellow River, respectively, to identify some social and environmental factors that may have affected the development of house structures across northern China. Our results show that the shape and size of the houses developed at a different pace, but in general followed a similar developmental sequence: (1) 10-8 ka BP, the bud of settlements emerged in the middle and lower reaches of the Yellow River; (2) 8-7 ka BP, people started to construct small pithouses without walls; (3) 7-6 ka BP, people made medium-sized pithouses with low walls, and surface buildings were made with a wood skeleton and mud walls; (4) 6-5 ka BP, ultra-large houses emerged; (5) 5-4 ka BP, house form became more varied, including pithouses, cave dwellings and surface buildings with a wood skeleton mud wall, rammed earth wall, piled mud-grass mixed walls and adobe walls; and (6) 4-3 ka BP, original palaces emerged. Our analyses indicate that the environment played an essential role in determining the house changes over time and that the early to middle Holocene's warm and humid climate provided excellent conditions for the emergence of settlements throughout the region. Due to the shortage of trees, people chose to change their house construction methods to accommodate the growing lumber shortage. In conclusion, the rapid shift in house construction methods reflects the changing ecological condition as well as a feedback cycle between the environment and social practices driven by resource limitations.
\end{abstract}

Keywords: Yellow River Basin; Neolithic-Bronze Age; house evolution; human-land interaction

\section{Introduction}

Around the world, houses are a fundamental part of sedentary agriculturalists' lifeways. The first permanent house structures likely originated once people started to transition from a highly mobile lifestyle to one more focused on perennial or annual sedentism. 
The shape and structure of houses reflects both human adaptations to environmental conditions as well as common practices and social structures that can be found within a community [1-3]. Therefore, household archaeology has rapidly become a fruitful area of research that complements and expands the scope of both environment and settlement archaeology $[4,5]$.

Over the past several decades, Chinese archaeologists have conducted a significant amount of archaeological work in the Yellow River Basin, revealing changes in house structure from the earliest Neolithic to the Bronze Age. While many houses have been excavated along the upper, middle and lower reaches of the Yellow River, there is as of yet no scientific analysis of the different dimensions or construction methods of these houses. According to the current state of archaeological knowledge, it appears that the shape and structure of ancient houses have distinctive characteristics in different regions, periods and environmental conditions. By quantifying these changes in house structure, we can better understand how human-land interaction changed over time.

In this paper, we collected data on the shape and size of Neolithic-Bronze Age houses to identify when and how the house structures changed in different areas of the Yellow River Basin. Using these data, we then compare our results with available paleoenvironmental datasets to identify the interaction between construction activities and environmental changes.

\section{The Development of Houses from the Neolithic to the Bronze Age in the Yellow River Basin}

The Yellow River is usually divided into upper, middle and lower reaches based on the macro topography of China. These three regions were also the major ancient cultural regions during the Neolithic and Bronze Age (Figure 1). Given these broad divisions, we selected sites typical of each region to examine how house shape and size changed from the Neolithic to the Bronze Age in the Yellow River Basin.

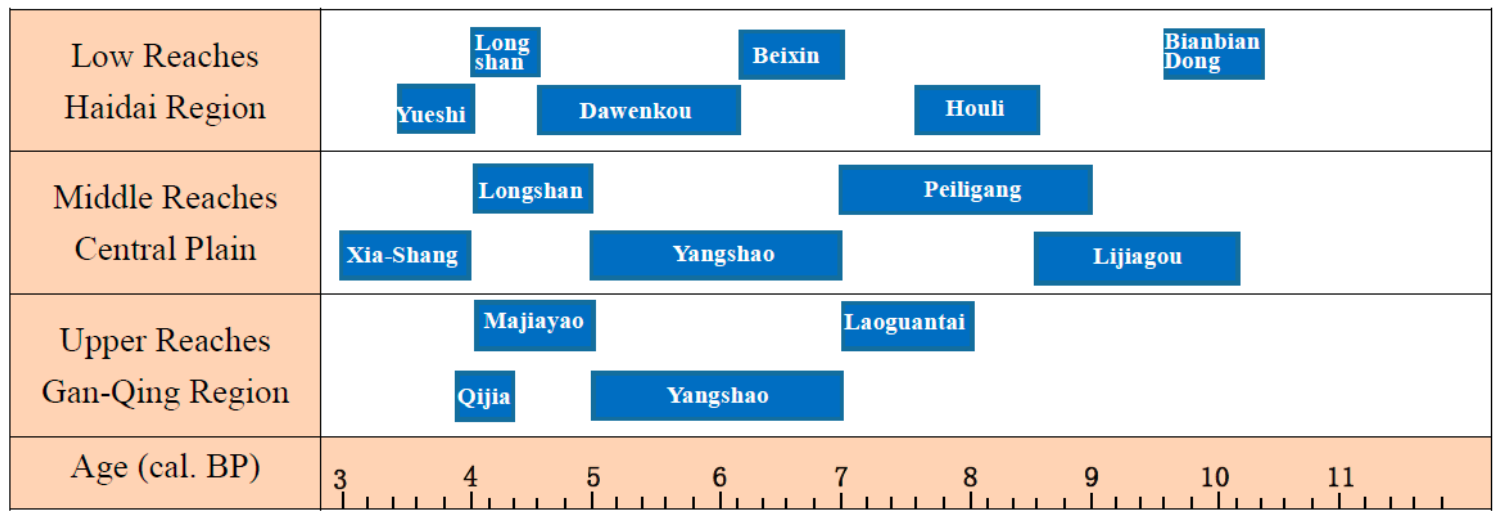

Figure 1. Archaeological cultural sequence and chronology during the Neolithic-Bronze Ages in the Yellow River Basin.

\subsection{Lower Yellow River Region}

The lower reaches of the Yellow River are mainly located in modern Shandong province, and some of the surrounding areas. The earliest signs of settlement during the Neolithic appear at the Bianbiandong site in the region, a cave site located in the middle mountain areas (Figure 2). Although archaeologists have not found any houses at the site, some evidence suggests the cave had been steadily occupied for a long time. The thick cultural sediments at the site indicate that there had been intensive human activities in the cave. Humans had maintained the area by leveling surfaces and putting down sandy sediment [6]. Pottery was also believed to be a part of the material assemblage of sedentary agriculturalists. Bones and charcoal found at Bianbiandong have been radiocarbon dated to $9550-10,120 \mathrm{cal}$ BP. The evidence from Bianbiandong suggests that people settled the area since the late Pleistocene to the early Holocene. 


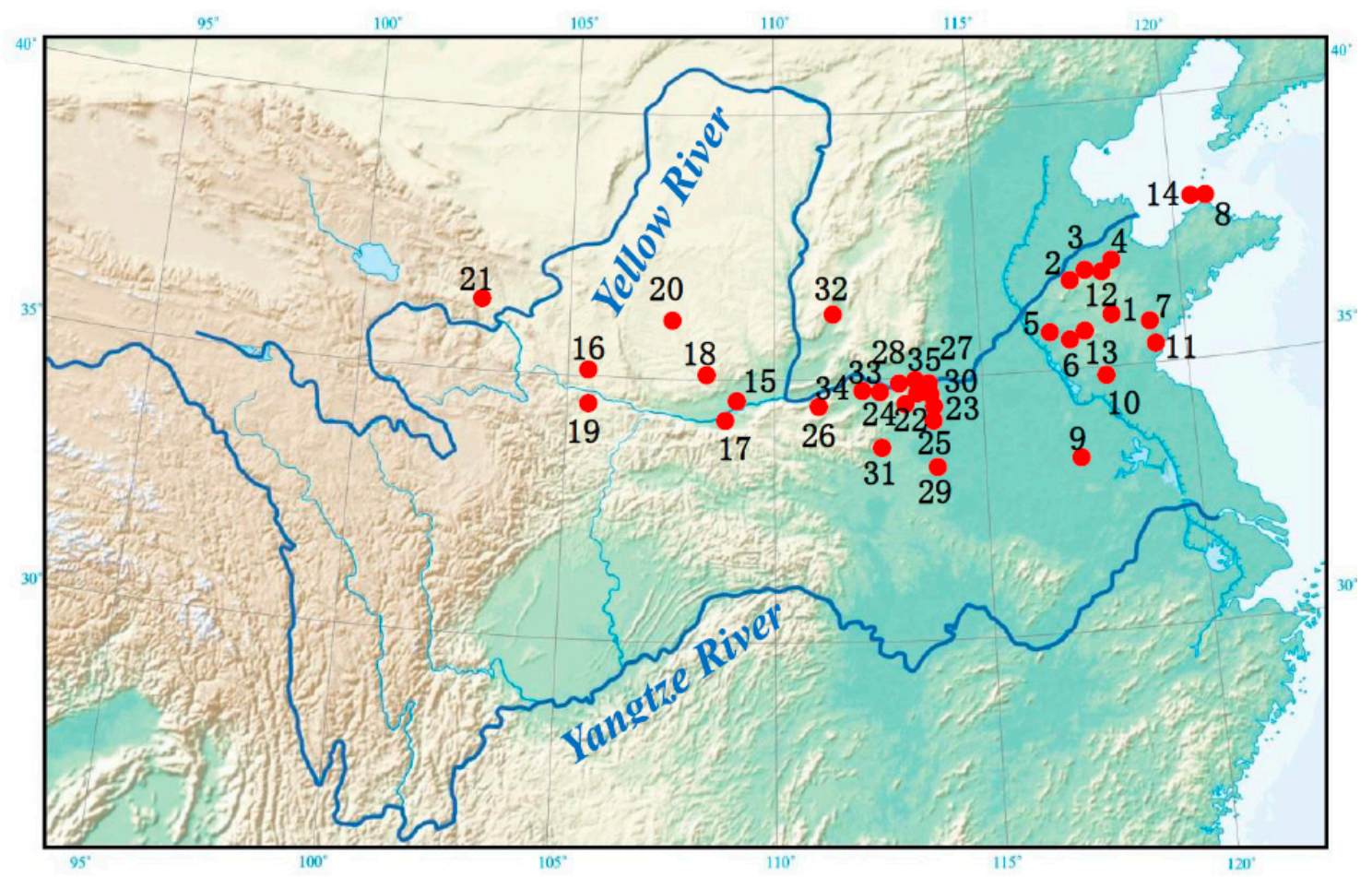

Figure 2. The location of typical sites with ancient house remains. (1) Bianbiandong; (2) Xihe; (3) Xiaojingshan; (4) Houli; (5) Dongjiabai; (6) Wangyin; (7) Chengzi; (8) Beizhuang; (9) Yuchisi; (10) Jianxin; (11) Yaowangcheng; (12) Fangjia; (13) Yinjiacheng; (14) Dakou; (15) Baijiacun; (16) Dadiwan; (17) Jiangzhai; (18) Lijiagou (Tongchuan); (19) Shizhaocun; (20) Chuangshan; (21) Lajia; (22) Lijiagou (Xinmi); (23) Tanghu; (24) Egoubeigang; (25) Shigu; (26) Xipo; (27) Dahecun; (28) Dianjuntai; (29) Haojiatai; (30) Guchengzhai; (31) Wadian; (32) Taosi; (33) Erlitou; (34) Zaojiaoshu; (35) Zhengzhoushangcheng.

The earliest houses in the lower Yellow River region dates to the Houli Culture (8500-7500 BP). Typical house remains have been found at Houli cultural sites like Xihe and Xiaojinshan (Table 1). All of the houses are of a same type: the semi pithouse (Figures 3 and 4). This is a simple architectural form that is composed of a dug-out cave and a wooden roof. At the Xihe Site, the depth of the dugout is usually no more than $0.5 \mathrm{~m}$. These buildings are called shallow pithouses. According to their size, all houses are divided into three types: a large house, with an area over $60 \mathrm{~m}^{2}$; a middle-sized house of 20-60 $\mathrm{m}^{2}$; and a small house, with an area less than $10 \mathrm{~m}^{2} .{ }^{14} \mathrm{C}$ data showed that the layer containing these houses dates to $8400-7700 \mathrm{cal} \mathrm{BP}$ and $7660-7000 \mathrm{cal} \mathrm{BP}[7,8]$. At the Xiaojinshan Site, the houses are around $20-60 \mathrm{~m}^{2}$. In addition to the shallow pithouses, some houses are dug deeper than $0.5 \mathrm{~m}$ [9], and these houses are called deep pithouses. 

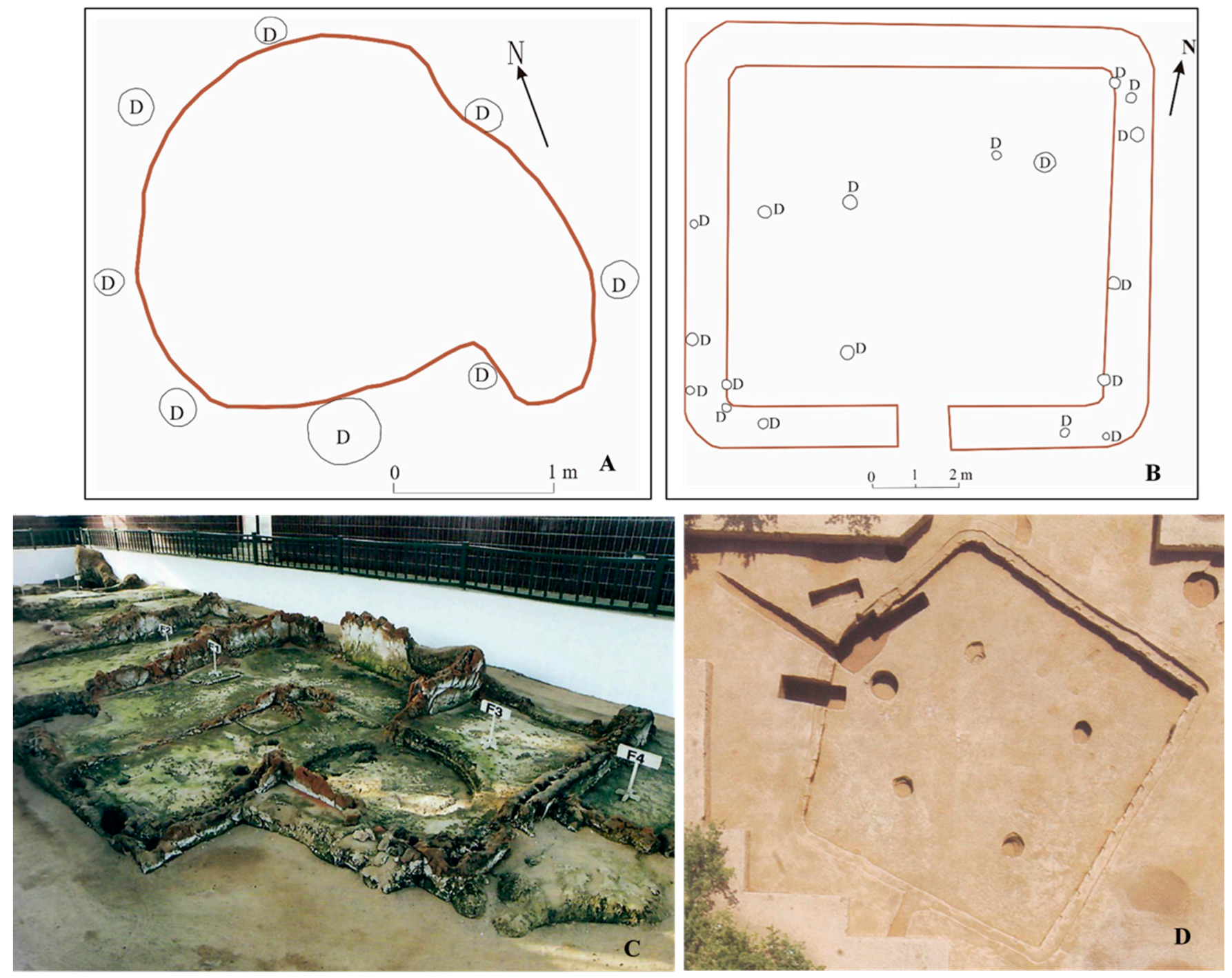

Figure 3. The floor plans and photos of the early houses. (A) The floor plans of the round semi pithouse; it was redrawn from F21 of the Tanghu site [10]. D = pillar hole. (B) The floor plans of surface building; it was redrawn from F74 of the Jiangzhai site [11]. D = pillar hole. (C) The floor photo for F1-4 of the Dahecun site, it cites from ZICRA (2001) [12]. (D) The floor photo for F106 of the Xipo site, it cites from Li XW et al (2015) [13].

A few houses dating to the Beixin culture (7000-6100 BP) have been found. The most Beixin houses have been found at Houli and Dongjiabai. All of them are semi pithouses with small areas (10-20 $\mathrm{m}^{2}$ ). These buildings are all deep pithouses, with a depth of $0.68 \mathrm{~m}$ at the Houli site [14]. At the Dongjiabai site, the cave depth is between 0.75 and $1.5 \mathrm{~m} \mathrm{[15]}$; however, there are no radiocarbon dates from these two sites, making absolute chronological control difficult. 

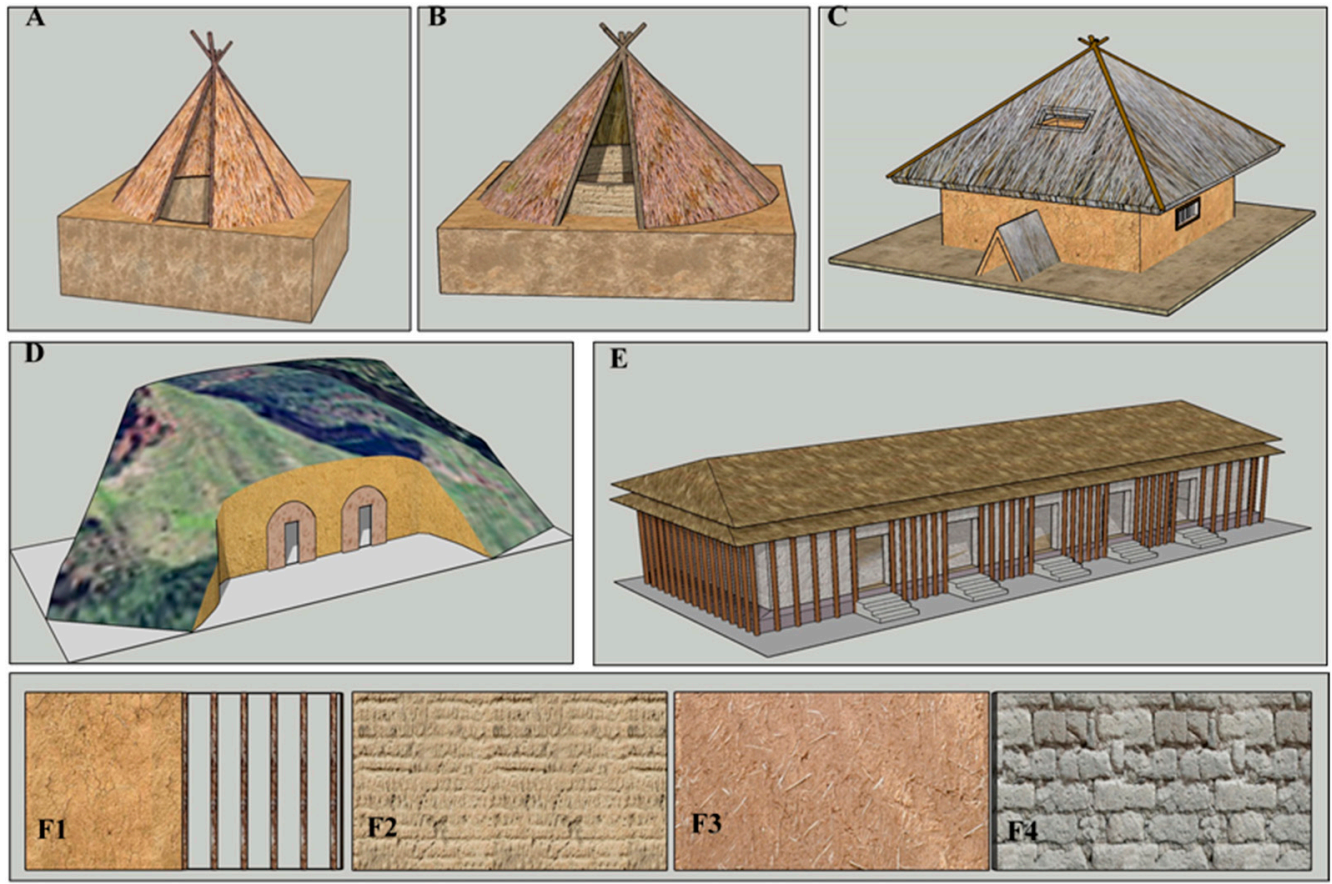

Figure 4. The shapes and forms of ancient houses: (A) semi pithouse without walls; (B) semi pithouse with low walls; (C) surface building; (D) cave dwelling; (E) palace, it was redrawn from HPICRA (2001) [16]; (F1) wood skeleton mud wall; (F2) rammed earth wall; (F3) piled mud-grass mixed wall; (F4) adobe wall.

The Dawenkou culture (6100-4600 BP) is usually divided into three phases. During the early-Dawenkou periods, houses appear very similar to the Beixin cultural remains. At the Wangyin site, all houses are deep pithouses. The depth of the house cave is $0.6-1.08 \mathrm{~m}$, and the size is $20-30 \mathrm{~m}^{2}$ in general. ${ }^{14} \mathrm{C}$ ages of $5950 \pm 125 \mathrm{cal}$. BP suggests that these houses fall into the extent of the early-Dawenkou periods [17,18]. During the middleDawenkou periods, a new type of house emerged in the lower Yellow River, "the wood skeleton mud wall" house, which is a surface building. Specifically, there are many tree branches in the mud walls that form the skeleton of the building. The houses found at the Chengziya Site are emblematic of these types of houses. Radiocarbon dates place these houses at $5550 \pm 165 \mathrm{cal}$. BP, the middle Dawenkou phase [19]. Although new types of houses emerged, the pithouses were widespread during the middle-Dawenkou phase. At the Beizhuang Site, all the houses found on site are half pithouses. The size of the house is usually $10-35 \mathrm{~m}^{2}$. Deep and shallow pithouses were found at the site. Their ${ }^{14} \mathrm{C}$ ages of 5100-5400 BP belonged to the middle Dawenkou periods. During the late-Dawenkou period, buildings on the surface became increasingly popular. At the Jianxin site, all houses that date to the late Dawenkou culture are surface buildings with the typical "wood skeleton mud wall" [20]. Similar buildings are found at the Yuchisi site. Not only are all the houses found at the site surface buildings, some houses are linked together to form a row house. The radiocarbon dates returned an age of $4850-4450$ cal. BP, dating to the late-Dawenkou culture [21,22].

During the Longshan culture period (4600-3900 BP), the type of house changed again. At the Yaowangcheng site, only one of six houses was a ground surface building with a "wood skeleton mud wall". The other five houses were adobe walls, which were constructed directly into the ground. These houses are not as large as the pithouses and have an area of around $10-20 \mathrm{~m}^{2}$. Unfortunately, there are no radiocarbon dates from these houses. Archaeologists concluded their date to the Longshan periods in term of relevant archaeological remains [23]. In the meantime, half pithouses were still used in the region. This type of house has been found in many Longshan cultural sites, such as Fangjia. 
During the Yueshi culture period (3900-3500 BP), both semi pithouses and surface buildings were used in the lower Yellow River region. At the Yinjiacheng site, all Yueshi cultural houses are surface buildings. The size is $5-30 \mathrm{~m}^{2}$. Although the walls were seriously damaged, it appears similar to the "wood skeleton mud wall" from the remains. Two radiocarbon dates from the layer containing the house remains returned ages of $3520 \pm 125$ cal. BP and $3715 \pm 135$ cal. BP [24]. The Yueshi cultural houses found at the Dakou site are all half pithouses. They are shallow pithouses with a depth of $0.45 \mathrm{~m}$. There are also small houses with an area of no more than $10 \mathrm{~m}^{2}$ [25].

\subsection{Upper Yellow River Region}

Archaeologists often think of the Upper Yellow River as the Gansu-Qinghai region where many Neolithic-Bronze Age sites are located. Because the Gansu-Qinghai region is similar to the cultures found in the Guanzhong Plain, especially before the Yangshao culture, we added some materials from the Yangshao and Pre-Yangshao sites in the Guanzhong Plain when we discuss the development of ancient houses in the upper reaches of the Yellow River.

Up to now, no early sites that date to around 10,000 BP have been discovered in the Gansu-Qinghai region. The earliest Neolithic culture is the Laoguantai culture, which dates to $8000-7000$ BP. This culture was mainly distributed across the area now in modern Shanxi and Gansu provinces. House remains have been found at the Baijiacun and Dadiwan sites. All houses are half pithouses, but some differences in shape and structure exist between these two sites. At Baijiacun, the houses are shallow pithouses that are $0.4-0.45 \mathrm{~m}$ deep. The size is less than $10 \mathrm{~m}^{2}$. Radiocarbon dating showed the ages are 7050-7330 BP [26]. At Dadiwan, the houses are deep pithouses with a depth of $0.7-1 \mathrm{~m}$. The size is also less than $10 \mathrm{~m}^{2}$. The layer containing house remains dates to $7350 \pm 115 \mathrm{BP}$ [27].

The Yangshao culture can be divided into three phases, namely, the early (7000-6000 BP), middle (6000-5500 BP) and late phases (5500-5000 BP). Early-Yangshao houses have been found both in Guanzhong and Gan-Qing. At Jiangzhai, the surface buildings start to appear during the early-Yangshao. These buildings have the typical "wood skeleton mud walls". Half pithouses were still commonly found at Jiangzhai. These houses included both deep and shallow dugouts. They are different than the Laoguantai culture because these houses have some low walls with a height of no more than $0.5 \mathrm{~m}$. These low walls do not support the weight of the roof [28]. Their function is more like an earthen table to put objects on. According to their size, all early-Yangshao houses at Jiangzhai can be divided into large houses $\left(>70 \mathrm{~m}^{2}\right)$, medium houses $\left(10-20 \mathrm{~m}^{2}\right)$ and small houses $\left(4-5 \mathrm{~m}^{2}\right)$. Three radiocarbon dates returned the following age ranges: $6824 \pm 135 \mathrm{BP}, 6673 \pm 198 \mathrm{BP}$ and $6563 \pm 151 \mathrm{BP}$, respectively [11]. At the Tongchuan Lijiagou site, no shallow pithouses were found by archaeologists. The early-Yangshao houses only include surface buildings and deep dugout houses. The houses are usually smaller, with an area of only 5-10 $\mathrm{m}^{2}$ or 20-40 $\mathrm{m}^{2}$. The cave depth is 0.6-1.2 m [29]. At Dadiwan, early-Yangshao houses are semi pithouses that are $0.5-1 \mathrm{~m}$ deep. Some houses have low walls. The size of the houses can be divided into large houses with an area of greater than $56 \mathrm{~m}^{2}$, medium house with an area of $25-56 \mathrm{~m}^{2}$ and small houses with an area of less than $25 \mathrm{~m}^{2}$. Radiocarbon ages shows that the date is $5490 \pm 120$ to $6440 \pm 190$ cal BP [27].

During the middle-Yangshao phase, the difference between the shape and structure of the houses is more obvious than between the Guanzhong and Gan-Qing Region. At Jiangzhai, all middle-Yangshao houses only include ground surface buildings with wood skeleton mud walls and semi pithouses with shallow caves. Some pithouses also have low walls. Most houses are small, with only one house larger than $50 \mathrm{~m}^{2}$. In general, the house area is around $5-15 \mathrm{~m}^{2}$. The radiocarbon dates returned ages of $5780 \pm 97 \mathrm{cal} \mathrm{BP}$ [11]. At Dadiwan, all middle-Yangshao houses are semi pithouses. The cave depth is $0.5-1 \mathrm{~m}$. Some houses have low walls. Radiocarbon dates returned a date of $5600 \pm 120$ cal BP [27].

Since the late-Yangshao period, the culture feature of Gan-Qing Region has its own unique characteristics. At the Dadiwan site, all late-Yangshao houses are ground surface 
buildings. These houses can be divided into three types: large houses are over $100 \mathrm{~m}^{2}$, medium houses are $40-100 \mathrm{~m}^{2}$ and small houses are less than $40 \mathrm{~m}^{2}$. There is a super large house among the large houses. The area of F901 is more than $400 \mathrm{~m}^{2}$. The house is a suite with a main room, three side rooms and some ancillary buildings. Two ${ }^{14} \mathrm{C}$ dates from F901 are $5080 \pm 190$ and $5045 \pm 190 \mathrm{cal}$ BP [27]. In Shizhaocun, the houses are all semi pithouses. They are small houses with an area of less $10 \mathrm{~m}^{2}$. The cave depth is $0.45-0.65 \mathrm{~m}$. The ${ }^{14} \mathrm{C}$ date shows the age of the houses is $5291 \pm 155 \mathrm{cal} \mathrm{BP}$ [30].

During the Majiayao culture (5000-4000 BP), cave dwellings became a new type of house form in the Gan-Qing Region. At Changshan, the Majiayao houses had the obvious characteristics of cave dwellings. They were dated to $4880 \pm 180 \mathrm{cal}$. BP [31]. Pithouses are still the most common in the region. At the Shizhaocun site, some Majiayao pithouses were found and dated to 4980-4732 cal. BP. They are usually $10-30 \mathrm{~m}^{2}$, including both deep and shallow cave types [30].

During the Qijia period (4400-3600 BP), houses were mainly cave dwellings and pithouses. At the Lajia site, many Qijia houses are cave dwellings [32]. At Shizhaocun, both cave dwelling and pithouses were found at the site. These pithouses are about $10 \mathrm{~m}^{2}$. They are often as deep as $0.5-1 \mathrm{~m}$. The age is $4088-3856$ cal. BP [30].

After the Qijia culture, many Bronze Age cultures appeared in the Gan-Qing region. Although some of them still made a settled life, people became more mobile. In the later period, some people of the Bronze Age cultures gave up settling down and became nomadic.

\subsection{Middle Yellow River Region}

The area of the middle reaches of the Yellow River mainly refers to Henan Province and the surrounding region. The earliest Neolithic culture in the region is Lijiagou, which is represented by the Xinmi Lijiagou site. The cultural deposit in the site dates to the early Neolithic around 10,500-8600 BP [33]. Some artificial rock gathering areas and pottery sherds were found at the site, indicating that changes to habitation style occurred during the early Neolithic. The animal bones and plant remains also reflected that the prehistoric inhabitants had changed their lifeways from a highly mobile society to a sedentary society [34].

After the Lijiagou culture, the Peiligang culture (9000-7000 BP) emerged in the region. The Peiligang house remains have also been found at Tanghu, Egoubeigang and Shigu. These sites are located on different landforms. Tanghu is located on a low terrace, Shigu on a high terrace and Egoubeigang is on a hill. Over 60 houses were found at Tanghu [35]. All houses are semi pithouses with an area of about $10 \mathrm{~m}^{2}$. The cave depth is usually $0.2-0.6 \mathrm{~m}$. At the Shigu site, all Peiligang houses are also semi pithouses. The area is usually less than $10 \mathrm{~m}^{2}$. The depth of cave is deeper, usually $0.5-1 \mathrm{~m}$ deep. Two radiocarbon dates from the layers containing the houses date to $7295 \pm 85 \mathrm{BP}$ and $7010 \pm 85 \mathrm{BP}$ [36]. Some semi pithouses were also found at the Egoubeigang site. The area is usually $5-10 \mathrm{~m}^{2}$. The depth of the cave is usually over $0.5 \mathrm{~m}$. There are also two radiocarbon dates, which are $7240 \pm 80 \mathrm{BP}$ and $7265 \pm 160 \mathrm{BP}$, respectively [37].

During the early-Yangshao periods, the shape and structure of the houses in the middle reaches were very similar to the Guanzhong Plain. At the middle-Yangshao, oversized houses appeared at some sites. At the Xipo site, some of the houses have an area between 200 and $500 \mathrm{~m}^{2}$. The largest house is even had an excess $500 \mathrm{~m}^{2}$ [38]. All of them are semi pithouses. The depth of the house cave is usually deeper, at $0.6-1 \mathrm{~m}$. Some houses have the low walls on the ground, which has the function to carry the weight of the roof $[13,39]$.

During the late-Yangshao period, besides a few semi pithouses, most houses are surface buildings. At Dahecun, many surface houses were found during the excavation. These houses are square with the size of 1-100 $\mathrm{m}^{2}$. Some houses are even connected together and formed a typical rowhouse. Most houses have a wood skeleton and mud walls. The layer containing these houses is dated to $4930 \pm 260$ and $5500 \pm 125 \mathrm{cal} \mathrm{BP}$ [12]. In the loess tableland area, some ground surface buildings were also found at the Dianjuntai 
site where they found square houses with an area of about $25 \mathrm{~m}^{2}$. The radiocarbon date shows the age of house sites dates to $5225 \pm 125 \mathrm{cal} \mathrm{BP}$ [40].

During the Longshan period (5000-4000 BP), house forms exhibited many diverse features. At the Haojiatai site, there were surface buildings, row houses and semi pithouses. None of these houses were large and the wood skeleton and mud wall construction method was also relatively rare. Instead, rammed earth walls and piled mud-grass mixed walls are much more common. Most of the semi pithouses are shallow dugout types that have a depth of less than $0.2 \mathrm{~m}$. Radiocarbon dates showed that the age of the houses is $4606 \pm 121$ cal BP [41]. At the Guchengzhai site, an extra-large large house was found; it is a square surface building with an area of $383.4 \mathrm{~m}^{2}$. This house also has an attached gallery building. The building group is built of wood skeleton and mud walls, and thought to be the antecessor of a palace [42]. Both the surface building and half pithouses of the Longshan culture were found at another mesa site, the Wadian Site. The surface buildings are larger. The pithouses are relatively small, with an area of about $5 \mathrm{~m}^{2}$. They are shallow pithouses with a $0.16-0.45 \mathrm{~m}$ cave. The radiocarbon date shows that the age of these houses is around 4055-3705 cal. BP [43]. In the hilly area, some cave dwellings were found at the Taosi Site, in addition to the semi pithouses. The pithouse also had a deep cave with a depth of about $0.5-1 \mathrm{~m}[44,45]$. 
Table 1. The basic feature of the typical sites and ancient houses (the sites are arranged in chronological order).

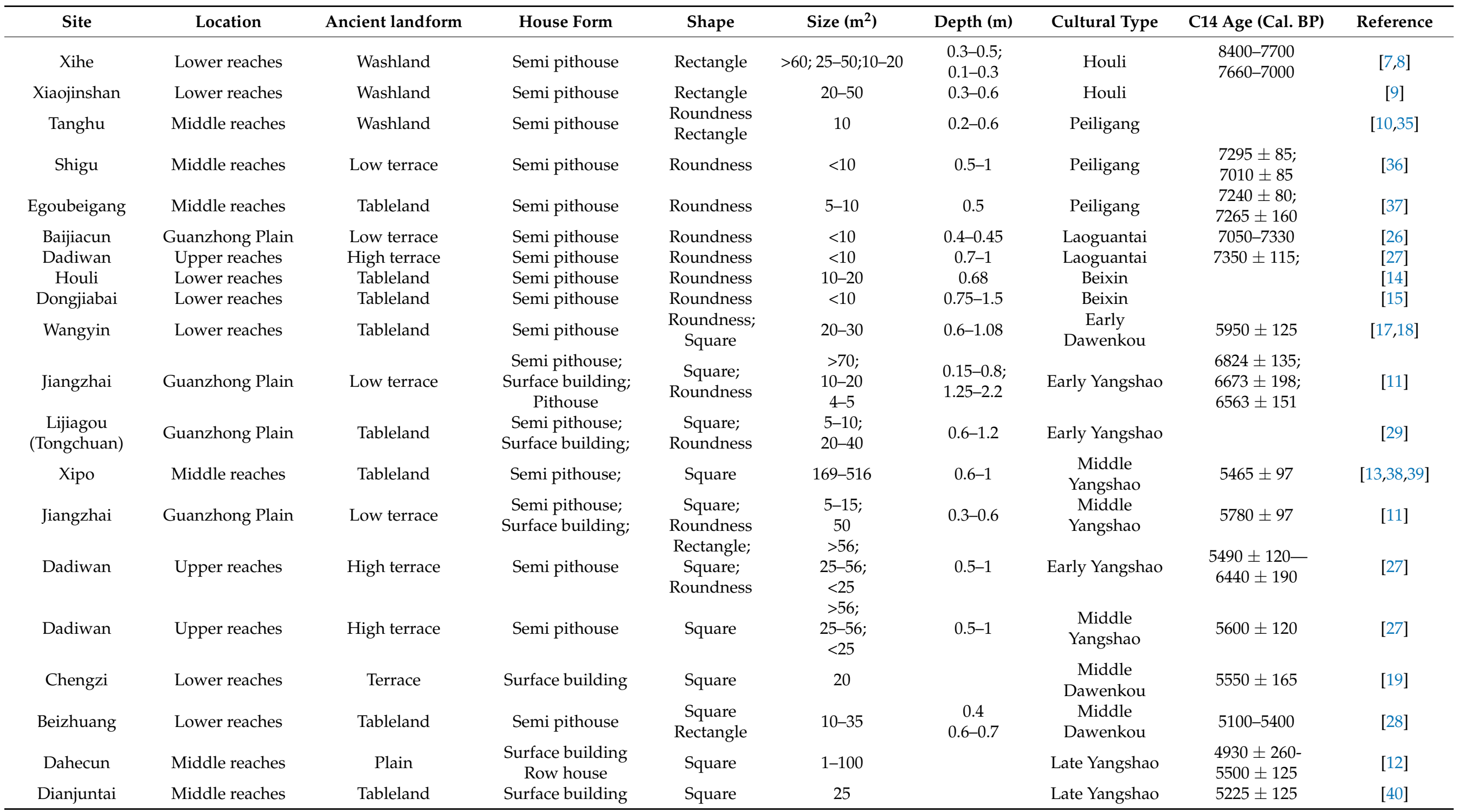


Table 1. Cont.

\begin{tabular}{|c|c|c|c|c|c|c|c|c|c|}
\hline Site & Location & Ancient landform & House Form & Shape & Size $\left(m^{2}\right)$ & Depth (m) & Cultural Type & C14 Age (Cal. BP) & Reference \\
\hline Dadiwan & Upper reaches & High terrace & Surface building & $\begin{array}{l}\text { Rectangle; } \\
\text { Square; }\end{array}$ & $\begin{array}{l}>100 \\
40-100 \\
\quad<40\end{array}$ & & Late Yangshao & $\begin{array}{l}5080 \pm 190 \\
5045 \pm 190 \\
5045 \pm 180\end{array}$ & [27] \\
\hline Yuchisi & Lower reaches & Plain & $\begin{array}{c}\text { Surface } \\
\text { buildingRow house }\end{array}$ & Square & $10-30$ & & Late Dawenkou & $4850-4450$ & {$[21,22]$} \\
\hline Jianxin & Lower reaches & Terrace & Surface building & $\begin{array}{l}\text { Rectangle } \\
\text { Square } \\
\text { Roundness }\end{array}$ & 10-20 & & Late Dawenkou & & [20] \\
\hline Yaowangcheng & Lower reaches & Tableland & $\begin{array}{c}\text { Adobe house } \\
\text { Surface building }\end{array}$ & Square & 10-20 & & Longshan & & [23] \\
\hline Fangjia & Lower reaches & Tableland & Semi pithouse & Square & $5-10$ & $0.75-0.95$ & Longshan & & [48] \\
\hline Haojiatai & Middle reaches & Plain & $\begin{array}{l}\text { Surface building } \\
\text { Row house } \\
\text { Semi pithouse }\end{array}$ & $\begin{array}{l}\text { Square } \\
\text { Roundess }\end{array}$ & $5-20$ & 0.14 & Longshan & $4606 \pm 121$ & [41] \\
\hline Guchengzhai & Middle reaches & High terrace & Surface building & Square & 383.4 & & Late Longshan & & [42] \\
\hline Wadian & Middle reaches & High terrace & $\begin{array}{l}\text { Semi pithouse } \\
\text { Surface building }\end{array}$ & Square & $\begin{array}{l}10-50 ; \\
5\end{array}$ & $0.16-0.45$ & Late Longshan & 4055-3705 & [41] \\
\hline Changshan & Upper reaches & Tableland & Cave dwelling & Roundness & 10 & & Changshanxia & $4880 \pm 180$ & [31] \\
\hline Shizhaocun & Upper reaches & High terrace & Semi pithouse & $\begin{array}{c}\text { Square } \\
\text { Roundness }\end{array}$ & $10-30$ & $0.3-0.9$ & Majiayao & $4980-4732$ & [30] \\
\hline Yinjiacheng & Lower reaches & Low terrace & Surface building & Square & $5-30$ & & Yueshi & $\begin{array}{l}3520 \pm 125 \\
3715 \pm 135\end{array}$ & [24] \\
\hline Dakou & Lower reaches & Terrace & Semi pithouse & Square & 10 & 0.45 & Yueshi & & [25] \\
\hline Erlitou & Middle reaches & Plain & $\begin{array}{l}\text { Surface building } \\
\text { Palace } \\
\text { Semi pithouse }\end{array}$ & $\begin{array}{c}\text { Square } \\
\text { Roundness }\end{array}$ & $\begin{array}{l}10-20 \\
>500\end{array}$ & 0.5 & Erlitou & 3700 & [46] \\
\hline Zaojiaoshu & Middle reaches & Plain & Semi pithouse & Square & $5-20$ & 0.5 & Erlitou & $3660 \pm 150$ & {$[47]$} \\
\hline $\begin{array}{l}\text { Zhengzhou } \\
\text { Shang City }\end{array}$ & Middle reaches & Plain & $\begin{array}{l}\text { Surface building } \\
\text { Palace } \\
\text { Semi pithouse }\end{array}$ & $\begin{array}{l}\text { Square } \\
\text { Roundess }\end{array}$ & $\begin{array}{c}5 \\
20 \\
400\end{array}$ & 0.5 & Erligang & 3570-3390 & [16] \\
\hline Lajia & Upper reaches & High terrace & Cave dwelling & Square & 15 & & Qijia & & [32] \\
\hline Shizhaocun & Upper reaches & High terrace & $\begin{array}{l}\text { Semi pithouse } \\
\text { Cave dwelling }\end{array}$ & $\begin{array}{c}\text { Square } \\
\text { Roundness }\end{array}$ & 10 & $0.5-1$ & Qijia & $4088-3856$ & [30] \\
\hline
\end{tabular}


From 4000 to 3000 BP, the first state-level society in China appeared in the middle reaches of the Yellow River. There are a lot of house sites that date to this period in the region. At capital settlements, like Erlitou and Zhengzhou Shang City, some magnificently large palace sites were found. These palaces are all surface buildings with wood skeletons and mud walls that are often over $400 \mathrm{~m}^{2}$. In addition to the palaces, a large number of surface buildings were also found in the sites. These houses, which are smaller in size, were widely distributed in the residential and workshop areas. Most of them are adobe or rammed earth houses [16,46]. Although the surface buildings had become the major types, there were still some semi pithouses in the region. They were the main situation at some sites. At the Zaojiaoshu site, all houses are semi pithouses. They are square houses with an area of $5-20 \mathrm{~m}^{2}$. The cave is shallower and the depth is about $0.5 \mathrm{~m}$. The radiocarbon date showed that the age is $3660 \pm 150$ cal. BP [47].

\subsection{Overall Characteristics of the Yellow River Basin}

The houses at these sites can be divided into two semi pithouses and surface buildings. These houses can also be further divided into deep pithouses without walls, shallow pithouses without walls, pithouses with low walls, wood skeleton mud wall, rammed earth wall, piled mud-grass mixed wall, adobe wall and cave dwellings. We numbered them 1-8 in Table 2. According to their size and function, the houses can be also divided into small, medium, large and ultra-large-sized houses, as well as palaces. They are also numbered A-E (Table 3). In this way, we can examine the developmental characteristics of the Neolithic-Bronze houses in the Yellow River Basin (Figure 5).

Table 2. Form categories of the ancient houses $(\mathrm{CD}=$ cave depth; $\mathrm{WH}=$ wall height; the model code is the same as in Figure 4).

\begin{tabular}{cccc}
\hline Form & Shape and Structure & Character & Model Code \\
\hline \multirow{3}{*}{ Half crypt types } & Deep cave without walls & CD: $>0.5 \mathrm{~m}$ & 1 \\
& Shallow cave without walls & CD: $<0.5 \mathrm{~m}$ & 2 \\
& Shallow cave with low walls & CD: $<0.5 \mathrm{~m}, \mathrm{WH}:<0.5 \mathrm{~m}$ & 3 \\
\hline & Wood skeleton mud walls & WH: $1 \mathrm{~m}$ & 4 \\
Surface buildings & Rammed earth walls & WH: $1 \mathrm{~m}$ & 5 \\
& Piled mud-grass mixed walls & WH: $1 \mathrm{~m}$ & 6 \\
& Adobe walls & & 7 \\
& Cave dwellings & & 8 \\
\hline
\end{tabular}

Table 3. Size classification of the ancient houses. (the model code is the same as in Figure 4).

\begin{tabular}{cccccc}
\hline Types & Small House & Medium House & Large House & $\begin{array}{c}\text { Ultra-Large } \\
\text { House }\end{array}$ & Palace \\
\hline Area & $<20 \mathrm{~m}^{2}$ & $20-60 \mathrm{~m}^{2}$ & $60-200 \mathrm{~m}^{2}$ & $>200 \mathrm{~m}^{2}$ & \\
Model code & $\mathrm{A}$ & $\mathrm{B}$ & $\mathrm{C}$ & $\mathrm{D}$ & $\mathrm{E}$ \\
\hline
\end{tabular}

The earliest houses emerged around 8-7 kBP in each reach of the Yellow River. They are all small semi pithouses. This house type has been widely used in the basin during the Neolithic-Bronze Age. During the Zhou Dynasty, this dwelling gradually disappeared.

The ancient houses developed along this trajectory in the Yellow River Basin:

- $\quad 10-8 \mathrm{ka} \mathrm{BP}$, the origins of the sedentary houses;

- $\quad$ 8-7 ka BP, small semi pithouses without walls;

- $\quad$ 7-6 ka BP, medium semi pithouses with low walls and surface buildings with wood skeleton and mud walls;

- 6-5 ka BP, ultra-large house emergence; 
- $\quad$ 5-4 ka BP, form diversification including pithouses, cave dwellings and surface buildings with wood skeleton mud walls, rammed earth walls, piled mud-grass mixed walls or adobe walls;

- $\quad$ 4-3 ka BP, palace emergence in the middle reaches.
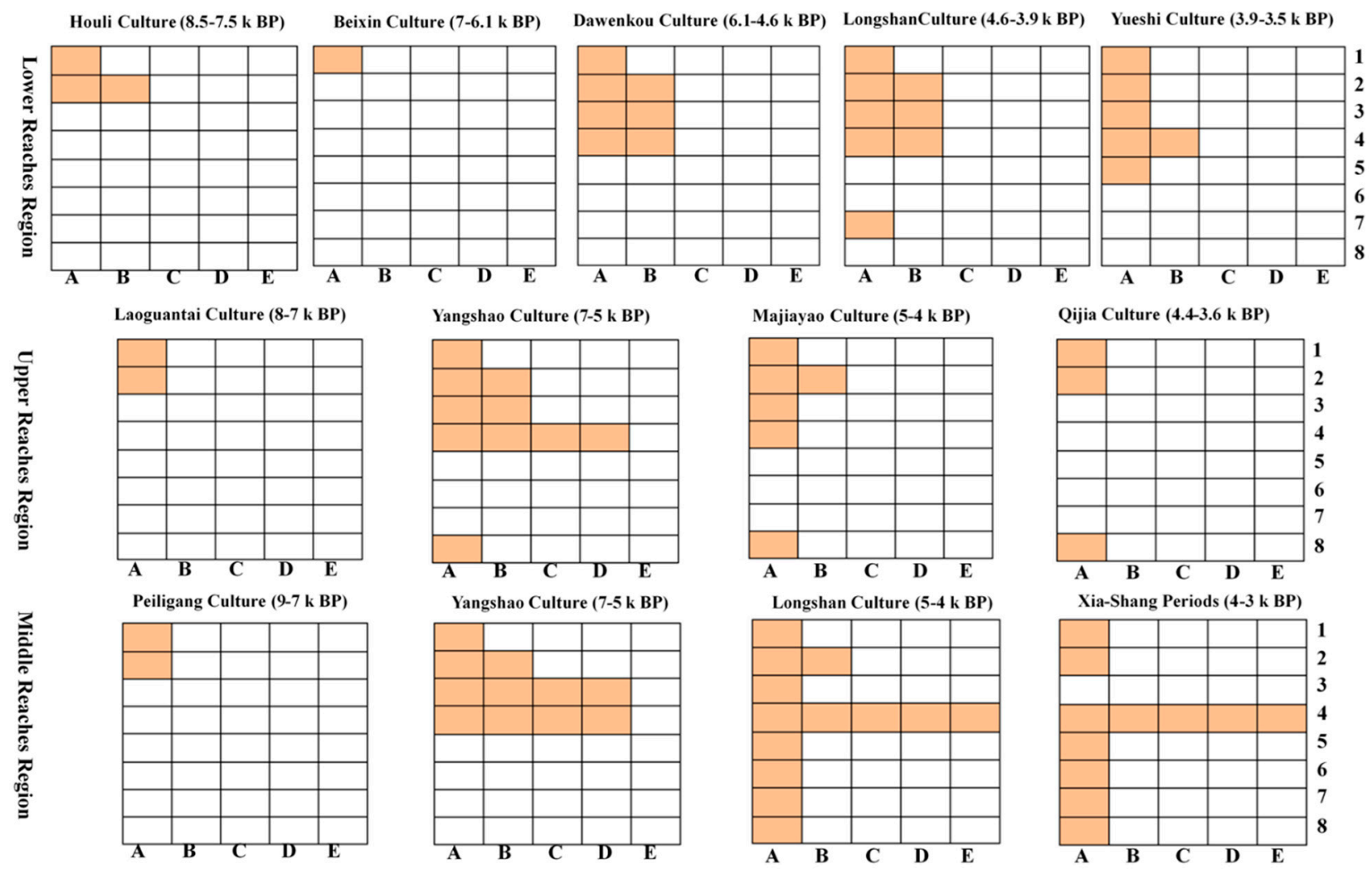

Figure 5. The house evolution in different areas (orange indicates the presence of such houses and white indicates the absence of evidence of these houses. The model code is the same as in Tables 1 and 2. The details are as follows: (A) small house; (B) medium house; (C) large house; (D) ultra-large house; (E) palace; and (1) deep pit house without walls; (2) shallow pit house without walls; (3) shallow pit house with low walls; (4) surface building with wood skeleton mud walls; (5) surface building with rammed earth walls; (6) surface building with piled mud-grass mixed walls; (7) surface building with adobe walls; (8) cave dwellings).

\section{Human-Land Interaction from the Perspectives of House Evolution}

\subsection{Environmental Impaction on House Evolution}

Paleoclimate research shows that the climate during the Holocene experienced significant fluctuations in the Yellow River Basin. Precipitation reconstructions from Gonghai Lake suggest that that a gradually intensifying monsoon process from 14,700-7000 BP radically increased the amount of rainfall than at present [49]. A maximum monsoon lasted from $7800-5300 \mathrm{BP}$, when precipitation was 30\% higher than at present. Since $3300 \mathrm{BP}$, monsoon strength and the amount of precipitation began to rapidly decline. Holocene temperature was consistent with the precipitation changes. The temperature reconstruction in the northern latitude (36, east longitude of 141.8) suggests that the temperature was fluctuating during the early Holocene [50]. This reached a peak from 8000 to $5000 \mathrm{BP}$, and then followed a process of decline with fluctuations (Figure 6).

With the increase in temperature and precipitation in the early Holocene, early houses began to emerge in the Yellow River Basin. The earliest houses were all pithouses. When the warm and humid climate began to reach their maximum from 7000-6000 BP, people started to use surface buildings to improve the humid conditions inside the pithouses. After $5000 \mathrm{BP}$, the regional climate began to change to dry and cool. Cave dwellings, rammed earth walls, piled mud-grass mixed walls and adobe walls all appeared in this 
period. As the climate continued to dry and cool, some people in ecologically fragile areas, like the upper reaches, even gave up their sedentary lifeway and became pastoralists after $3000 \mathrm{BP}$.

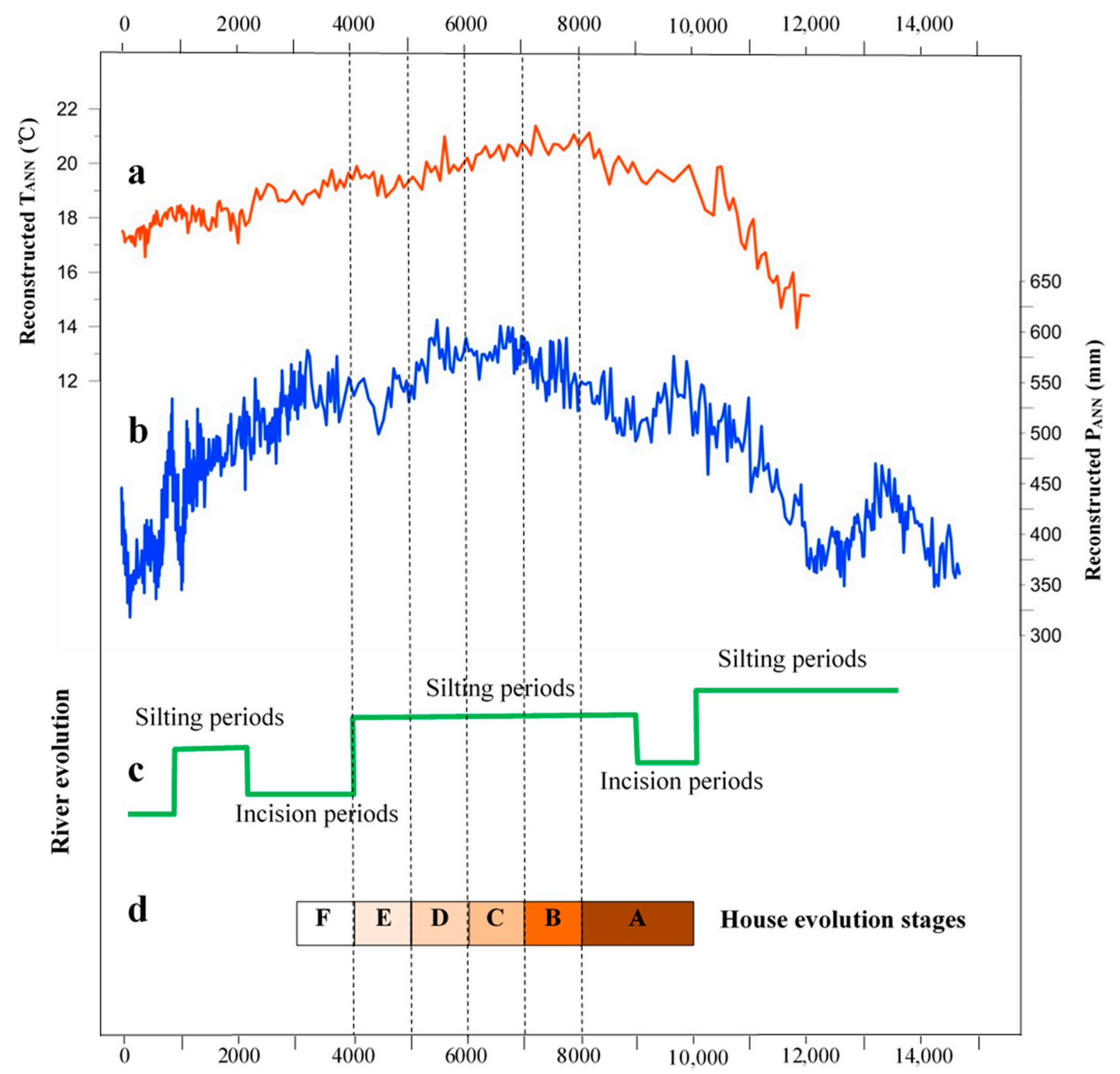

Age (Cal yr BP)

Figure 6. The relationship between house evolution and the Holocene environment: (a) temperature reconstruction, it citesfrom Chen et al (2015) [49]; (b) precipitation reconstruction, it cites from Marcott et al (2013) [50]; (c) fluvial geomorphic evolution; (d) house evolution. (A) The emergence of permanent settlements; (B) small semi pithouse without walls; (C) medium semi pithouse with low walls and surface buildings with wood skeleton mud walls; (D) ultra-large house emergence; (E) form diversification; (F) palace emergence and the formation of regional residential forms.

As a result of the climate fluctuation, rivers started to cycle through periods of aggradation and incision many times in the Yellow River Basin. In the middle Yellow River, the Holocene layers of silt are found in many small river basins [51,52]. Analysis of the age and sedimentary facies of these silting layers showed that the river evolution during the Holocene generally follows a similar process. At the end of the late Pleistocene, rivers were aggrading for a long time. During 10-9 kBP, the rivers started to incise their course. During 9-4 kBP, the rivers switched over to aggradation once again, and then the rivers began to 
incise. During historical periods, rivers repeat this silting and incision [53]. Similar patterns have also been observed in the lower [54] and the upper Yellow River [55]. These implied that the river evolution during the Holocene had a similar process in the drainage basin.

River evolution also had a deep impact on the prehistoric houses. The shape and form of these houses showed a distinct difference in different geomorphic position. In the high terrace of the loess areas, most pithouses were deep cave types during 8-7 kBP. However, the lower terrace areas were dominated by shallow cave types. The high underground water level caused by the river aggradation seriously affected the depth of the house cave. From 7-4 kBP, the appearance of surface buildings was also related to the increasingly flooding rivers. After the river incision, the loess sections appeared in many river valleys, creating natural conditions for the use of cave dwellings in the drainage basin.

\subsection{Building Activity Impaction on Landscape}

In northern China, after the buildings with a wood skeleton and mud walls became common around $7000 \mathrm{BP}$, we hypothesize that the demand for lumber for house construction rapidly increased. Many trees around the settlements may have been cut down for house construction and other uses. Forests may have been clear cut near settlements. Pollen analysis shows that there was a significant reduction in tree pollen after $5.5 \mathrm{k} \mathrm{BP}$ at many sites like Dahecun [56] and Dadiwan [57]. These findings imply that human activities had an impact on regional vegetation. In turn, the scarcity of trees affected human activity in building houses. People were forced to change their house construction methods due to the shortage of trees. Cave dwellings, rammed earth walls, piled mud-grass mixed walls and adobe walls were common for a long time in the Yellow River Basin.

Although the natural environment profoundly influenced the emergence and evolution of the early houses, the cultural factors were also very significant in the process. At first, the settlements corresponded to an agricultural society; nomads used more makeshift camps. Secondly, technological innovation plays an important role in the evolution of houses. This is reflected in the evolution of the semi-cave to ground buildings and the rise of brick and wood structure buildings in the later period. Finally, economic conditions were crucial to the evolution of the early houses; it directly determines the distribution range and evolutionary time node of a particular house form.

\section{Conclusions}

Different types of ancient houses appear in different areas and at a different spatial distribution, but in general experienced the following evolution process in the Yellow River Basin: (1) 10-8 ka BP, the origins of the sedentary houses; (2) 8-7 ka BP, small pithouses without walls; (3) 7-6 ka BP, medium pithouses with low walls and surface buildings emergence; (4) 6-5 ka BP, ultra-large house emergence; (5) 5-4 ka BP, form diversification, including pithouses, cave dwellings, surface buildings with wood skeleton mud, rammed earth and piled mud-grass mixed or adobe walls; and (6) 4-3 ka BP, palace emergence in the middle reaches of the Yellow River Basin.

The environment played a key role in shaping the developmental process of houses in the Yellow River basin. A warm and humid climate provided ideal natural conditions for the emergence and development of ancient houses during the Holocene. River silting in the middle Holocene deeply affected the shape and distribution of ancient houses.

Human construction activities also impacted the regional environment. We argue that people cut down many trees from 7000-5500 BP, leading to a widespread lumber shortage and a sharp reduction in the number of forests. As a result of the scarcity of trees, cave dwellings, rammed earth walls, piled mud-grass mixed walls and adobe walls were used for a long time afterwards. The development of housing structures from the Neolithic to the Bronze Age in the Yellow River basin reveals the that natural environment is a fundamental component in human activities and people usually seek out the means suitable for their own needs, so as to develop their unique cultures. 
Author Contributions: Conceptualization, P.L., D.M. and Y.T.; methodology, P.L.; software, P.C.; validation, P.L., D.M. and Y.T.; formal analysis, L.Y.; investigation, H.W., X.W., J.X., L.J. and Zhang. L.; data curation, X.W.; writing-original draft preparation, P.L. and Y.T.; writing-review and editing, P.L. and M.S.; visualization, P.C. and L.Y.; project administration, P.L. and D.M. All authors have read and agreed to the published version of the manuscript.

Funding: The study is funded by the National Natural Science Foundation of China (Grant Nos. 41971016, 41671014, 41701014 and 41807018), the National Social Science Foundation of China (Grant Nos. 18CKG003 and 19ZDA227), Science and technology project of Henan Province (Grant Nos. 192102310019), Soft Science Research Project of Henan Province (Grant No. 192400410067) the Study of Environment archaeology in Zhengzhou, the Digital Environment Archaeology Speciallyappointed Researcher of Henan, China (Grant No. 210501002), the basic scientific research of Henan (200601079, 210601027), the Research on the Roots of Chinese Civilization of Zhengzhou University (XKZDJC202006) and the Science and Technology Think-Tank Project of Henan Academy of Sciences (Grant No. 210701002).

Conflicts of Interest: The authors declare no conflict of interest.

\section{References}

1. Guilaine, J. Maisons néolithiques: Exemples méditerranéens. In L'archéologie des Maisonnées-Pour une Approche Comparative Transatlantique, Actes du Colloque Inter-National, 24 et 25 Octobre 2014; dans Chapdelaine, C., Burke, A., Gernigon, K., Eds.; Université de Montréal, P@lethnologie: Montréal, QC, Canada, 2016; Volume 8, pp. 189-216.

2. Westgate, R.; Whitley, N.F. Building Communities: House, Settlement and Society in the Aegean and Beyond the British School at Athens; Senate House, Malet Street, London WC1E 7HU @The Council, the British School at Athens: Athens, Greek, 2007.

3. Madella, M.; Kovacs, G.; Berzsenyi, B.; Godino, I.B. The Archaeology of Household; Oxbow Books: Oxford, UK, 2019.

4. Yang, H.X. Discussion on the development of residential Architecture of Yangshao Culture. Acta Archaeol. Sin. 1975, 1, 39-72. (In Chinese with English Abstract).

5. Qian, Y.P. The emergence of cave dwelling architecture and its significance of environmental archaeology. Cultural Relic 2004, 2, 69-77. (In Chinese)

6. Sun, B.; Cui, S.K. Discussion on the early Neolithic remains in Shandong Region. Cult. Relics Cent. China 2008, 3, 23-28. (In Chinese with English Abstract).

7. Liu, Y.C.; Lan, Y.F.; Tong, P.H. Excavation of the Xihe Neolithic Site in Zhangqiu City, Shandong in 1997. Archaeology 2000, 10, 15-28. (In Chinese with English Abstract).

8. Wang, Z.B.; Zhang, S.K.; Zhang, Z.X.; Sun, T.; Zhang, Z.G. Excavation of the Xihe Neolithic Site in Zhangqiu City in 2008. Haidai Archaeol. 2012, 5, 67-138. (In Chinese)

9. Wang, S.G.; Ning, Y.T. Investigation and excavation of the Xiaojinshan Site in Zhangqiu City, Shandong. Huaxia Archaeol. 1996, 2, 1-23. (In Chinese with English Abstract).

10. Xin, Y.J.; Hu, Y.Y.; Zhang, Y.Q.; Liu, Q.B. Excavation of Peiligang remains of Tanghu Site in Xinzheng City, Henan in 2007. Archaeology 2010, 5, 3-23. (In Chinese with English Abstract).

11. XBM; SPIA; LM. Jiangzhai-Excavation Report of Neolithic Site; Cultural Relics Publishing House: Beijing, China, 1988. (In Chinese)

12. ZICRA. Zhengzhou Dahecun; Science Press: Beijing, China, 2001. (In Chinese)

13. Li, X.W.; Yang, H.Q.; Guo, Z.W.; Hou, Y.F. Excavation of two Miaodigou type big house sites in Xipo site of Lingbao City, Henan. Archaeology 2015, 5, 3-16. (In Chinese)

14. Wang, Y.B.; Wang, S.G.; Li, Z.G.; Ni, G.S. The first and second excavation of Houli Site in Linzi, Shanding. ArchaeologyI 1992, 11, 987-996. (In Chinese)

15. Hu, B.H. Excavation bulletin of the Neolithic Dongjiabai Site in Wenshang County, Shandong. Archaeology 1993, 6, 461-467. (In Chinese)

16. HPICRA. The Site of Shang Dynasty City in Zhengzhou; Cultural Relics Publishing House: Beijing, China, 2001. (In Chinese)

17. $\mathrm{Hu}$, B.H. Excavation bulletin of the Neolithic Wangyin Site in Yanzhou, Shandong. Archaeology 1979, 1, 5-14. (In Chinese)

18. CASS. Shandong Wangyin-Excavation Report of the Neolithic Site; Science Press: Beijing, China, 2000. (In Chinese)

19. Du, Z.Z. A report on the excavation of the Chengzi Site in Zhucheng County, Shandong Province. Acta Archeol. 1980, 3, 329-385. (In Chinese with English Abstract).

20. He, D.L. Dawenkou Culture remains of Zaozhuang Jianxin site. Huaxia Archaeol. 1998, 4, 47-56. (In Chinese with English Abstract).

21. Zhang, L.; Zhang, W.D.; Wang, J.H. Excavation of Yuchisi Site in Mengcheng County, Anhui in 2003. Archaeology 2005, 10, 867-888. (In Chinese with English Abstract).

22. Huo, D.F. Staging and chronology of Yuchisi type remains in Yuchisi Site. Huaxia Archaeol. 2010, 4, 71-80. (In Chinese with English Abstract).

23. Li, Y.T. Excavation of Yaowangcheng Longshan culture site in Rizhao. Prehist. Res. 1985, 4, 51-64. (In Chinese)

24. ASHDSU. Yinjiacheng Site at Sishui; Cultural Relics Publishing House: Beijing, China, 1990. (In Chinese with English Abstract). 
25. Wu, R.Z. Dakou Site in Tuoji Island, Changdao County, Shandong Province. Archaeology 1985, 12, 1068-1083. (In Chinese)

26. CASS. Litong Baijiazhuang; Bashu Publishing House: Chengdu, China, 1994. (In Chinese)

27. GICRA. Qinan Dadiwan: Excavation of Neolithic Site; Cultural Relics Publishing House: Beijing, China, 2006. (In Chinese)

28. Yan, W.M. Research on Yangshao Culture: Revised and Enlarged Edition; Cultural Relics Press: Beijing, China, 2009. (In Chinese)

29. Zhang, R.L.; Gao, Q. Excavation of Neolithic Lijiagou Site in Tongchuan. Archaeol. Cult. Relics. 1984, 1, 5-33. (In Chinese)

30. CASS. Shizhaocun and Xishanping; The Encyclopedia of China Publishing House: Beijing, China, 1999. (In Chinese)

31. $\mathrm{Hu}$, Q.Y. Excavation of Changshan site in Zhenyuan, Longdong. Archaeology 1981, 3, 201-210. (In Chinese with English Abstract).

32. Ren, X.Y.; Wang, G.D.; Cai, L.H.; He, K.Z.; Ye, M.L. Excavation of Lajia Site in Minhe County, Qinghai in 2000. Archaeology 2002, 12, 1068-1081. (In Chinese)

33. Wang, Y.P.; Zhang, S.L.; He, J.N. The major gains of the archaeological excavation in Lijiagou Site, Xinmi, Henan. Cult. Relics Cent. China 2011, 1, 4-6. (In Chinese with English Abstract).

34. Wang, Y.P.; Zhang, S.L.; Wang, S.Z. Excavation bulletin of the south area of the Lijiagou Site in 2010 in Xinmi, Henan Province. Cult. Relics Cent. China 2018, 6, 38-45. (In Chinese with English Abstract).

35. Zhang, S.L.; Xin, Y.J.; Hu, Y.Y.; Yan, F.H. Excavation of Peiligang remains of Tanghu Site in Xinzheng City, Henan. Archaeology 2008, 5, 3-20. (In Chinese with English abstract).

36. Guo, T.S.; Chen, J.X. Excavation of Shigu Site in Changge. Huaxia Archaeol. 1987, 1, 3-125. (In Chinese)

37. Yang, Z.Q. Excavation of the Neolithic Egoubeogang Site in Mi County, Henan. Archaeology 1979, 5, 14-19. (In Chinese)

38. Wei, X.T.; Li, S.L. Yangshao Culture F105 house site in Xipo site of Lingbao, Henan. Cult. Relics 2003, 8, 4-17. (In Chinese)

39. Li, X.W.; Ma, X.L.; Yang, H.Q. A big house site in middle stage of Yangshao culture in Xipo site of Lingbao City, Henan. Archaeology 2005, 3, 3-6. (In Chinese)

40. Zhao, Q.; Zhang, S.L. Excavation of Xingyang Dianjuntai Site in 1980. Cult. Relics Cent. China 1982, 4, 3-24. (In Chinese)

41. HPICRA. Yancheng Haojiatai; Elephant Press: Zhengzhou, China, 2012; (In Chinese with English Abstract).

42. Cai, Q.F.; Ma, J.C. Excavation of Guchengzhai Longshan Culture Site in Xinmi, Henan. Huaxia Archaeol. 2002, 2, 53-82. (In Chinese with English Abstract).

43. HPICRA. Yuzhou Wadian; World Publishing Corporation: Beijing, China, 2004. (In Chinese)

44. Yan, Z.B.; He, N. Excavation on the City-site of Taosi, Xiangfan, Shanxi in 2002. Archaeology 2005, 3, 307-316. (In Chinese with English Abstract).

45. Gao, T.L.; Li, J.M. The main harvest of excavation on dwelling site in III Area of Taosi Site in 1983-1984. Archaeology 1986, 9 , 773-781. (In Chinese with English Abstract).

46. CASS. Erlitou: 1999-2006; Cultural Relics Publishing House: Beijing, China, 2014. (In Chinese)

47. LCRWT. Luoyang Zaojiaoshu; Science Press: Beijing, China, 2002. (In Chinese)

48. Zhang, S.K.; Wang, Z.B.; Xu, X. Excavation in Fangjia Site of Zibo City. Haidai Archaeol. 2011, 1, 30-65. (In Chinese)

49. Chen, F.H.; Xu, Q.H.; Chen, J.H.; Birks, H.J.B.; Liu, J.; Zhang, S.; Jin, L.; An, C.; Richard, J.T.; Cao, X.; et al. East Asian summer monsoon precipitation variability since the last deglaciation. Sci. Rep. 2015, 5, 11186. [CrossRef] [PubMed]

50. Marcott, A.S.; Jeremy DShakun, D.J.; Clark, U.P.; Mix, A.C. A Reconstruction of Regional and Global Temperature for the Past 11,300 Years. Sciences 2013, 339, 1198-1201. [CrossRef]

51. Xu, J.J.; Mo, D.W.; Wang, H.; Zhou, K.S. Preliminary research of environment archaeology in Zhenshui River, Xinmi City, Henan. Quat. Sci. 2013, 33, 954-964. (In Chinese)

52. Wang, H.; Zhang, H.; Zhang, J.F.; Fang, Y.M. Fluvial geomorphologic evolution and its related issues in Wadian Site of Yuzhou, Henan Province. South. Cult. Relics 2015, 4, 67-77. (In Chinese)

53. Lu, P.; Wang, H.; Chen, P.; Storozum, M.J.; Xu, J.; Tian, Y.; Mo, D.; Wang, S.; He, Y.; Yan, L. The impact of Holocene alluvial landscape evolution on an ancient settlement in the southeastern piedmont of Songshan Mountain, Central China: A study from the Shiyuan site. Catena 2019, 183, 104232. [CrossRef]

54. Wang, H.; Lan, Y.F.; Liu, Y.C.; Tong, P.H. The ancient landform and related issues of Xihe Site in Zhangqiu, Shandong Province. Cult. Relics South. China. 2016, 3, 141-147. (In Chinese with English Abstract).

55. An, C.B.; Ji, D.X.; Chen, F.H.; Dong, G.H.; Wang, H.; Dong, W.M.; Zhao, X.Y. The origin of prehistoric agricultural development in central Gansu: The cases of Qi'an and Lixian, Gansu. Sci. Bull. 2010, 55, 1381-1386. (In Chinese)

56. Yan, F.H.; Mai, X.S.; Ye, Y.Y. Geological ace and environment of the Dahecun site, Zhengzhou, from sporopoilen data. Seismol. Geol. 1986, 8, 69-74. (In Chinese)

57. Tang, L.Y.; An, C.B. Pollen record of Holocene vegetation change and drought events in Loess Plateau of Longzhong. Prog. Nat. Sci. 2007, 17, 1371-1382. (In Chinese) 